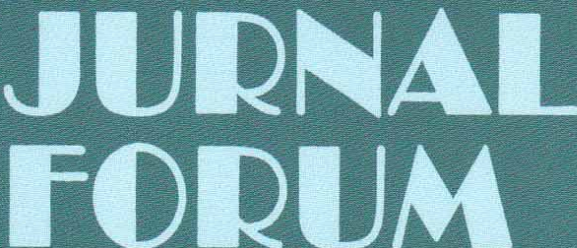

Volume 7 - Nomor 1

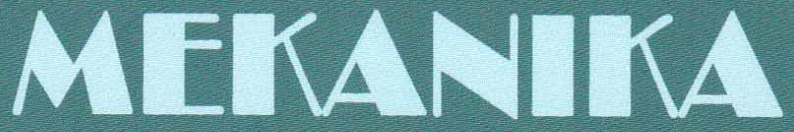

Mei 2018

ISSN : 2356-1491

PENGARUH FLY ASH DENGAN PENAMBAHAN CACAHAN KARET, SILICA FUME DAN SUPERPLASTICIZER TERHADAP BETON

TRI YUHANAH; TOMMY IDUWIN; BUDI WICAKSONO

PERILAKU STRUKTUR TOWER TRANSMISI TIPE SUSPENSION TERHADAP BEBAN ANGIN MUHAMMAD SOFYAN; DICKI DIAN PURNAMA; ABDUL ROKHMAN

IDENTIFIKASI PENYEBAB KECELAKAAN KERJA PADA PROYEK KONSTRUKSI BANGUNAN GEDUNG TINGGI

RETNA KRISTIANA; SLAMET

STUDI SIFAT MEKANIS TANAH MERAH DENGAN PENGUJIAN TRIAKSIAL REFFANDA KURNIAWAN RUSTAM

ANALISIS PENGARUH BESAR BUTIRAN AGREGAT KASAR TERHADAP KUAT TEKAN BETON NORMAL IKA SULIANTI; AMIRUDDIN; RIO SHAPUTRA; DARYOKO

ANALISIS BANJIR DAN TINGGI MUKA AIR PADA RUAS SUNGAI CILIWUNG STA 7+646 S/D STA $15+049$

IKA SARI DAMAYANTHI SEBAYANG; MELIANA PARLINA

ANALISIS KELAYAKAN PERENCANAAN PEMBANGUNAN JALAN PENGHUBUNG (MISSING LINK) ANTARA DESA SIKUR SAMPAI DESA PAOKMOTONG KABUPATEN LOMBOK TIMUR

DESSY ANGGA AFRIANTI; SIGIT IRFANSYAH; MEYRISSA PUTRI DEWANDARI 


\title{
PENGARUH FLY ASH DENGAN PENAMBAHAN CACAHAN KARET, SILICA FUME DAN SUPERPLASTICIZER TERHADAP BETON
}

\author{
TRI YUHANAH \\ Jurusan Teknik Sipil, Sekolah Tinggi Teknik - PLN \\ E-mail : triyuhanah@gmail.com. \\ TOMMY IDUWIN \\ Jurusan Teknik Sipil, Sekolah Tinggi Teknik - PLN \\ E-mail : tommy.iduwin@gmail.com \\ BUDI WICAKSONO \\ Jurusan Teknik Sipil, Sekolah Tinggi Teknik - PLN \\ E-mail : budi.wicaksono.bon@gmail.com
}

\begin{abstract}
Abstrak
Seiring dengan majunya perkembangan dilakukan gerakan aksi lingkungan, perusakan sistematis alam, mulai diusahakan untuk dikurangi, sehingga perlu adanya pemikiran penggunaan jenis sumber campuran baru yang dapat digunakan dalam pembuatan beton. Pemanfaatan limbah abu terbang (fly ash) dan cacahan karet pada beton diharapkan dapat menanggulangi dampak pencemaran lingkungan. Oleh karena itu, pengaruh variasi abu terbang (fly ash) dengan penambahan cacahan karet dan dengan bahan tambah (admixture) seperti silica fume dan superplasticizer pada campuran beton dapat meningkatkan kualitas pada beton. Sampel penelitian dibuat dengan perbandingan fly ash Bangka dengan fly ash Suralaya sebesar 0\%, 10\% dari berat semen dan cacahan karet $5 \%$ dari berat agregat halus dengan silica fume $4 \%$ dari berat semen yang sudah dikurangi dengan berat fly ash dan ditambah dengan superplasticizer sebesar $2 \%$ dari kebutuhan air. Pengujian sampel pada umur 7, 14, 28 hari, untuk mengetahui kekuatan tekan, slump maupun setting time beton.
\end{abstract}

Kata kunci : Fly Ash, Kuat Tekan, Setting Time, Silica Fume, Superplasticizer

\begin{abstract}
Along with the progress of environmental action movement, the systematic destruction of nature, began to be reduced, so it is necessary to think about the use of new types of mixed sources that can be used in the manufacture of concrete. Utilization of fly ash and rubber debris on concrete is expected to cope with the impact of environmental pollution. Therefore, the effect of variations of fly ash with the addition of rubber shards and with added materials (admixture) such as silica fume and superplasticizer on concrete mixes can improve the quality of concrete. The samples of the study were made by comparison of fly ash Bangka with fly ash Suralaya by 0\%, 10\% of the weight of cement and 5\% of fine weight aggregate with silica fume 4\% of the weight of cement that has been reduced by the weight of fly ash and supplemented by a superplasticizer of $2 \%$ water needs. Testing sample at age 7, 14, 28 days, to know compressive strength, slump and concrete time setting.
\end{abstract}

Keywords: Fly Ash, Strength, Setting Time, Silica Fume, Superplasticizer

\section{Latar Belakang}

Beton merupakan suatu material campuran yang terdiri dari pasir (agregat halus), kerikil (agregat kasar), semen, air dan dengan atau tanpa bahan tambahan (admixture) dengan perbandingan tertentu yang akan membentuk beton segar. Akan tetapi seiring dengan majunya perkembangan dilakukan gerakan aksi lingkungan, perusakan sistematis alam, mulai diusahakan untuk dikurangi, sehingga perlu adanya pemikiran penggunaan jenis sumber campuran baru yang dapat digunakan dalam pembuatan beton. Teknologi beton memungkinkan penggunaan limbah menjadi bahan dasar pembuatan beton sehingga di satu sisi penggunaan material yang berasal dari alam yang dapat merusak lingkungan dapat dibatasi, dan dilain sisi bahan 
limbah ini dapat dimanfaatkan seoptimal mungkin sebagai bahan material pembuatan beton. Dengan adanya fenomena tersebut, banyak orang mencoba memanfaatkan limbah untuk dipergunakan dalam campuran beton, seperti limbah plastik, limbah ban, limbah baja, limbah sterofoam dan abu terbang (Fly Ash).

Fly Ash dihasilkan dari pembakaran batu bara di PLTU, seiring dengan meningkatnya pembangunan PLTU berbahan bakar batu bara di Indonesia, maka jumlah limbah abu terbang juga akan meningkat. Jika limbah ini tidak dimanfaatkan secara besar-besaran akan menjadi masalah pencemaran lingkungan, yang mana dampak dari pencemaran akibat abu terbang (Fly Ash) sangat berbahaya baik bagi kesehatan, lingkungan dan limbah tersebut tergolong dalam limbah B-3. Limbah abu terbang dapat dimanfatkan sebagai bahan tambah pengganti semen. Penggunaan material fly ash sebagai material pembentuk beton didasari pada sifat material ini yang memiliki kemiripan dengan sifat semen. Kemiripan sifat ini dapat ditinjau dari dua sifat utama, yaitu sifat fisik dan kimiawi. Secara fisik, material fly ash memiliki kemiripan dengan semen dalam hal kehalusan butirbutirnya.

Penggunaan limbah padat sebagai substitusi material pada industri beton bukanlah hal yang baru. Namun penggunaan limbah padat sebagai pengganti agregat pada beton beberapa tahun belakangan ini semakin meningkat sebagai solusi yang cukup menjanjikan untuk mengurangi limbah padat yang bersifat anorganik (Nadim, Nasser, 2012) ${ }^{1}$. Limbah anorganik adalah limbah yang tidak dapat terurai oleh alam sehingga dapat dikatakan sebagai polusi lingkungan. Salah satu contoh limbah anorganik adalah limbah ban karet. Dimana, produksi ban tiap tahun terus meningkat sejalan dengan meningkatnya industri otomotif dan kebutuhan pasar domestik maupun untuk ekspor (Pane, 2012) ${ }^{2}$. Sehingga tiap tahun akan semakin banyak limbah ban yang tidak terpakai yang dapat menjadi polusi lingkungan. Berkaca dari hasil tersebut maka diperlukan alternatif dalam pengolahan limbah karet ban bekas tersebut. Salah satu sifat positif yang didapatkan dari limbah karet adalah sifatnya yang tahan terhadap air, memiliki sifat fleksibilitas dan lentur yang baik serta dapat meredam getaran. Pemakaian agregat yang diambil dari alam sebagai bahan pembuatan campuran beton secara ekonomis cukup mahal, maka pemakaian limbah ban bekas sebagai bahan substitusi untuk mengganti sebagian agregat halus dalam campuran beton menjadi alternatif agar dapat mereduksi pengeluaran biaya dan mengatasi pencemaran lingkungan akibat pembuangan limbah ban bekas dan diharapkan dapat menghasilkan suatu alternatif beton yang ramah lingkungan dan memiliki kemampuan dalam menahan beban.
Penelitian ini akan menggunakan bahan tambah seperti superplasticizer dan silica fume. Untuk pemakaian superplasticizer sendiri dalam campuran beton bisa mempermudah pelaksanaan serta mengurangi penggunaan air (dengan menggunakan faktor air semen kecil) pada beton sehingga beton memiliki mutu kekentalan yang tinggi. Mengurangi air pada beton itu sendiri untuk mendapatkan beton bermutu tinggi dan mencegah terjadinya keroposan akibat pemadatan yang tidak maksimal. Salah satu bahan superplasticizer yang akan digunakan dalam penelitian ini adalah sika viscocrete-3115N. Silca fume merupakan produk sampingan sebagai abu pembakaran dari proses pembuatan silicon metal atau silicon alloy dalam tungku pembakaran listrik. Mikrosilika ini bersifat pozzolan, dengan kadar kandungan senyawa silicadioksida $\left(\mathrm{SiO}_{2}\right)$ yang sangat tinggi $(>90 \%)$ dan ukuran butiran partikel yang sangat halus, yaitu sekitar 1/100 ukuran rata-rata partikel semen. Dengan demikian penggunaan mikrosilika pada umumnya akan memberikan sumbangan yang lebih efektif pada kinerja beton, terutama untuk beton bermutu sangat tinggi. Selain itu juga dapat meningkatnya ikatan pasta beton dengan agregat yang menghasilkan kekuatan beton lebih tinggi. Maka dari itu, untuk penggunaan silica fume sendiri untuk mengurangi jumlah semen pada campuran beton, sehingga dapat menanggulangi dampak pemakaian semen yang terlalu banyak.

Penambahan Superplasticizer dapat memperbaiki workability namun tidak terpengaruh besar dalam meningkatkan kuat tekan beton untuk faktor air semen yang diberikan. Namun pegunaan superplasticizer untuk beton mutu tinggi secara umum sangat berhubungan dengan dengurangan jumlah air dalam campuran beton. Superlasticizer yang digunakan yaitu Visconcrete $3115 \mathrm{~N}$, adalah bahan tambahan kimia yang termasuk dalam jenis Sulfonated naphthaleneformaldehyde condensates dan merupakan admixture tipe $\mathrm{F}$.

\section{Rumusan Masalah}

Rumusan masalah pada penelitian ini adalah :

1. Menentukan klasifikasinya abu terbang ( $f l y$ ash) dari Bangka dan Suralaya

2. Bagaimana pengaruh abu terbang ( fly ash) dari Bangka dan Suralaya dengan kadar 0\%, 10\% dari berat semen dengan cacahan karet 5\% dari berat agregat halus, bahan tambah superplasticizer dengan kadar $2 \%$ dari jumlah air dan silica fume dengan kadar $4 \%$ dari berat semen, terhadap kuat tekan beton dan kuat tarik belah beton, nilai slump test (workability), setting time beton?

3. Bagaimana pengaruh penggunaan fly ash dari Bangka dan Suralaya dangan cacahan karet 
dan bahan tambah silica fume dan superplasticizer pada beton K-375.

\section{Tujuan Penelitian}

Tujuan utama dari penelitian ini adalah untuk mengetahui kuat tekan beton, kuat tarik belah, nilai slump test serta setting time pada saat pengecoran beton, terhadap pengaruh menggunakan limbah abu terbang (fly ash) dari Bangka dan Suralaya 0\%, $10 \%$ dari berat semen, dengan cacahan karet 5\% dan bahan tambah superplasticizer sebesar $2 \%$ dari kebutuhan air serta silica fume $4 \%$ dari berat semen.

\section{Landasan Teori}

\section{Pengaruh Abu Terbang (Fly Ash)}

Pengaruh abu terbang dalam beton mutu tinggi adalah sifat Pozzolan dari abu terbang yang halus membuat beton lebih padat sehingga dapat memperkecil pori-pori pada beton dan dengan takaran yang tepat abu terbang terbukti dapat meningkatkan kekuatan beton (Mardiono, 2011) ${ }^{3}$. Metode ACI 211-4R-1993 yang dikombinasikan dengan metode Hasimoto semakin besar kadar abu terbang, maka kelecakan beton semakin bertambah, membuat adukan menjadi kohesif, tidak terjadi segregasi dan memperlambat pengikatan awal dan pengikatan akhir beton, (I Wayan Suamita,2011) ${ }^{4}$. Pemakaian abu terbang dalam campuran beton yang digunakan menurunkan hidrasi pada mass concrete. Hasilnya menunjukan bahwa pozzolan merupakan material yang dapat dimanfaatkan sebagai campuran beton dengan memberikan hasil yang cukup baik dan harganya relatif murah (Marzuki, 1996). Abu terbang atau bahan pozzolan lainnya yang digunakan sebagai bahan tambahan harus memenuhi "Spesifikasi untuk abu terbang dan pozzolan alami murni untuk digunakan sebgai bahan tambahan mineral pada beton semen portland" (ASTM C618). SNI 03-2460-1991 (Spesifikasi Abu Terbang Sebagai Bahan Tambahan untuk Campuran Beton) Menurut klasifikasinya abu terbang (fly ash) dapat dibedakan menjadi 3 jenis, yaitu :

a. Kelas C

- Abu terbang (Fly ash) yang mengandung $\mathrm{CaO}$ di atas $10 \%$, dan abu terbang (Fly ash) yang dihasilkan melalui pembakaran lignit atau batu bara dengan kadar karbon \pm $60 \%$ atau sub bitumen.

- $\quad \operatorname{Kadar}(\mathrm{SiO} 2+\mathrm{Al} 2 \mathrm{O} 3+\mathrm{Fe} 2 \mathrm{O} 3)>50 \%$.

- Kadar Na2O mencapai $10 \%$.

- Memiliki sifat pozzolanik dan hidrolis.

b. Kelas F

- Abu terbang (Fly ash yang mengandung $\mathrm{CaO}$ yang lebih kecil $10 \%$, dan abu terbang ( Fly ash) yang dihasilkan dari pembakaran batu bara jenis anthrchacite pada suhu $1560^{\circ} \mathrm{C}$ Abu terbang (Fly ash) ini mempunyai sifat pozzolan.

- $\operatorname{Kadar}(\mathrm{SiO} 2+\mathrm{Al} 2 \mathrm{O} 3+\mathrm{Fe} 2 \mathrm{O} 3)>70 \%$.

- Kadar Na2O < 5\%.

- Memiliki sifat pozzolanik dan hidrolis yang lebih tinggi dari abu terbang (Fly ash) C.

c. Kelas N

- Pozzolan alam atau hasil pembakaran yang dapat digolongkan antara lain tanah diatomic, opalinechertz dan shales, tuff dan abu vulkanik, dimana biasa diproses melalui pembakaran atau tidak melalui proses pembakaran. Selain itu juga mempunyai sifat pozzolan yang baik.

\section{Pengaruh Sillica Fume}

Silica fume adalah material pozzolan yang sangat halus yang sebagian besar terdiri dari unsur silica, yang dihasilkan dari tanur tinggi sebagai produk sampingan industri metal silikon (ASTM C 1240). Silica fume berwarna abu-abu, diameter butiran rata-rata $0,1 \mathrm{~m}$, dengan specific surface $20.000 \mathrm{~m}^{2} / \mathrm{kg}$, seperseratus kali lebih halus daripada semen, berat jenis silica fume 2,2 dan berat volumenya sebesar $200-300 \mathrm{~kg} / \mathrm{m}^{3}$ (Burge, 1988). Silica fume mengandung senyawa silikat yang sangat tinggi yaitu sekitar $93 \%$ (Ryan, 1992), senyawa silikat minimum pada silica fume sebesar $85 \%$ (ASTM C 1240-93) ${ }^{6}$. Adukan beton yang mengandung silica fume akan membutuhkan air yang lebih banyak, di atas 5 persen daripada beton tanpa silica fume, adukan beton lebih kohesif, sehingga tidak menimbulkan segregasi dan secara signifikan mengurangi terjadinya bleeding (ACI Committee 234). Kuat tekan beton yang mengandung silica fume pada umur 3 sampai 28 hari lebih besar daripada kuat tekan beton tanpa silica fume, kontribusi silica fume terhadap kuat tekan beton di atas umur 28 hari relatif kecil (ACI Committee 234)

\section{Pengaruh Superplasticizer}

Superlasticizer yang digunakan yaitu Visconcrete $3115 \mathrm{~N}$ adalah bahan tambahan kimia yang termasuk dalam jenis Sulfonated naphthaleneformaldehyde condensates dan merupakan admixture tipe F (Lisantono dan Hehanussa, 2009). Superplasticizer dapat memperbaiki workability namun tidak terpengaruh besar dalam meningkatkan kuat tekan beton untuk faktor air semen yang diberikan. Namun kegunaan superplasticizer untuk beton mutu tinggi secara umum sangat berhubungan dengan pengurangan jumlah air dalam campuran beton. Pengurangan ini tergantung dari kandungan air yang digunakan, dosis dan tipe dari superplasticizer yang dipakai.(L.J. Parrot, 1998). 


\section{Pengaruh Cacahan Karet}

Beton yang mengandung karet tidak menunjukkan brittle failure ketika pengujian kuat tekan dan kuat tarik belah. Sebuah analisis yang lebih mendalam dari hasil mereka menunjukkan potensi yang baik apabila menggunakan limbah ban sebagai campuran beton menggunakan semen portland karena meningkatkan ketangguhan dari retak. Namun, dibutuhkan mix design yang dapat mengoptimalkan kadar ban karet dalam campuran. Cacahan limbah ban karet yang terkadang disebut serbuk ban bekas yang diistilahkan dengan "tire crumb" atau "crumb rubber" adalah produk yang ramah lingkungan karena diperoleh dari ban bekas dan tidak larut dalam tanah ataupun air tanah.

\section{Komponen-Komponen Penyusun Beton}

Beton adalah campuran semen Portland, air, dan agregat dengan atau tanpa bahan tambahan (admixture) tertentu. Material pembentuk beton tersebut dicampur merata dengan komposisi tertentu yang menghasilkan suatu campuran yang homogen sehingga dapat dituang dalam cetakan untuk dibentuk sesuai keinginan. Campuran beton tersebut apabila dibiarkan akan mengalami pengerasan sebagai akibat reaksi kimia antara semen dan air yang berlansung selama jangka waktu panjang atau dengan kata lain campuran beton akan bertambah keras sejalan dengan umurnya. Berdasarkan SNI $2847: 2013^{8}$ beton (concrete) adalah campuran semen portland atau semen hidrolis lainnya, agregat halus, agregat kasar, dan air, dengan atau tanpa bahan campuran tambahan (admixture). Pemilihan bahan-bahan pembentuk beton yang mempunyai kualitas baik, perhitungan proporsi campuran yang tepat. Cara pengerjaan dan perawatan yang baik dan penambahan bahan tambah yang tepat dengan kadar yang optimum yang diperlukan akan menentukan kualitas beton yang dihasilkan. Berikut ini adalah penjelasan tentang bahan-bahan yang digunakan untuk membuat beton.

\section{Semen Portland}

Semen merupakan bahan ikat yang penting dan banyak digunakan dalam pembangunan fisik di sektor konstruksi sipil. Semen PPC dibuat dari semen hidraulis yang dihasilkan dengan cara menghaluskan klinker yang terbuat dari batu kapur $\left(\mathrm{CaCO}_{3}\right)$ yang jumlahnya sangat banyak serta tanah liat dan bahan dasar berkadar besi, terutama dari silikat-silikat kalsium yang bersifat hidraulis ditambah dengan bahan yang mengatur waktu ikat. Semen portland dibuat dengan melalui beberapa langkah, sehingga sangat halus dan memiliki sifat adhesif maupun kohesif. Bahan dasar semen Portland terdiri dari bahan-bahan yang mengandung kapur, silika, alumina, dan oksida besi

\section{Air}

Dalam pembuatan beton, air merupakan faktor yang sangat penting karena air dapat bereaksi dengan semen yang akan menjadi pasta pengikat agregat. Air juga berpengaruh terhadap kuat desak beton, karena jika kelebihan penggunaan air akan berakibat pada penurunan kekuatan beton tersebut. Sebaliknya jika kelebihan penggunaan air akan mengakibatkan beton menjadi bleeding, yaitu air bersama sama dengan semen akan naik ke atas permukaan adukan segar yang baru dituang. Berdasarkan SNI 2847 : 2013 ${ }^{8}$ air yang digunakan pada campuran beton harus memenuhi ASTM C1602M (Standar Spesifikasi untuk Air Campuran yang Digunakan dalam Produksi Beton Semen Hidrolis). Air untuk pembuatan beton minimal memenuhi syarat sebagai air minum yaitu tawar, tidak berbau, bila dihembuskan dengan udara tidak keruh dan lain-lain, tetapi tidak berarti air yang digunakan untuk pembuatan beton harus memenuhi syarat sebagai air minum.

\section{Agregat}

Agregat merupakan butiran mineral alami yang berfungsi sebagai bahan pengisian dalam campuran mortar dan beton. Agregat ini akan menempati sebanyak $60 \%$ sampai $80 \%$ dari volume mortar atau beton. Meskipun hanya sebagai bahan pengisi, namun agregat sangat berpengaruh terhadap sifat mortar atau beton, sehingga pemilihan agregat merupakan suatu bagian penting dalam pembuatan mortar atau beton. Berdasarkan ukuran butirnya, agregat yang dipakai dalam adukan beton dibedakan menjadi dua jenis yaitu agregat kasar dan agregat halus. Cara membedakan jenis agregat yang paling banyak dilakukan adalah dengan berdasarkan pada ukuran butiranbutirannya. Agregat yang mempunyai butiranbutiran yang besar disebut agregat kasar yang ukurannya lebih besar dari $4,75 \mathrm{~mm}$. Sedangkan butiran agregat yang kecil disebut agregat halus yang memiliki ukuran lebih kecil dari $4,75 \mathrm{~mm}$. Untuk menghasilkan beton dengan kekompakkan yang baik, diperlukan gradasi agregat yang baik. Gradasi agregat adalah distribusi ukuran kekerasan butiran agregat,gradasi diambil dari hasil pengayakan.

Berdasarkan ukurannya, agregat terbagi dua jenis, yaitu :

1. Agregat halus merupakan pasir alam sebagai hasil disintegrasi 'alami' dari batuan atau pasir yang dihasilkan oleh industri pemecah batu dan mempunyai ukuran butir terbesar 5,0 mm. (SNI 03-2847-2002) ${ }^{9}$

Tabel syarat batas gradasi agregat halus dapat dilihat pada tabel 2.1 
Tabel 1. Gradasi Jenis Kategori Zona Kehalusan Pasir

\begin{tabular}{|c|c|c|c|c|c|c|c|c|}
\hline \multirow{3}{*}{$\begin{array}{c}\text { Ayakan } \\
(\mathrm{mm})\end{array}$} & \multicolumn{8}{|c|}{ Berat Komulatif $(\%)$} \\
\hline & \multicolumn{2}{|c|}{$\begin{array}{l}\begin{array}{c}\text { Zonal } \\
\text { (Kasar) }\end{array} \\
\end{array}$} & \multicolumn{2}{|c|}{$\begin{array}{c}\text { Zona } 2 \\
\text { (Agak Kasar) }\end{array}$} & \multicolumn{2}{|c|}{$\begin{array}{l}\text { Zona 3 } \\
\text { (Halus) }\end{array}$} & \multicolumn{2}{|c|}{$\begin{array}{c}\text { Zona } 4 \\
\text { (Agak Halus) }\end{array}$} \\
\hline & Bawah & Atas & Bawah & Atas & Bawah & Atas & Bawah & Atas \\
\hline 10 & 100 & 100 & 100 & 100 & 100 & 100 & 100 & 100 \\
\hline 4.8 & 90 & 100 & 90 & 100 & 90 & 100 & 95 & 100 \\
\hline 2.4 & 60 & 95 & 75 & 100 & 85 & 100 & 95 & 100 \\
\hline 1.2 & 30 & 70 & 55 & 100 & 75 & 100 & 90 & 100 \\
\hline 0.6 & 15 & 34 & 35 & 59 & 60 & 79 & 80 & 100 \\
\hline 0.3 & 5 & 20 & 8 & 30 & 12 & 40 & 15 & 50 \\
\hline 0.15 & 0 & 10 & 0 & 10 & 0 & 10 & 0 & 15 \\
\hline
\end{tabular}

Sumber : SNI 03-2834-2000 ${ }^{10}$

2. Agregat kasar berupa kerikil sebagai hasil disintegrasi 'alami' dari batuan atau berupa batu pecah yang diperoleh dari industri pemecah batu dan mempunyai ukuran butiran antara $5 \mathrm{~mm}$ sampai $40 \mathrm{~mm}$ (SNI 03-28472002) ${ }^{9}$. Ukuran maksimum dari beton bertulang diatur berdasarkan kebutuhan agregat tersebut harus dengan mudah dapat mengisi cetakan dan lolos dari celah-celah yang terdapat diantara batang-batang baja tulangan.

Tabel 2. Syarat Gradasi Agregat Kasar

\begin{tabular}{|c|c|c|c|}
\hline \multirow{2}{*}{$\begin{array}{c}\text { Ukuran } \\
\text { Lubang } \\
\text { Ayakan } \\
(\mathrm{mm})\end{array}$} & \multicolumn{3}{|c|}{$\begin{array}{c}\text { Persentase Berat Bagian Yang Lewat } \\
\text { Ayakan }\end{array}$} \\
\cline { 2 - 4 } & \multicolumn{3}{|c|}{ Ukuran Nominal Agregat (mm) } \\
\cline { 2 - 4 } & 40 & 20 & 10 \\
\hline 38,1 & $95-100$ & 100 & - \\
\hline 19,0 & $37-70$ & $95-100$ & 100 \\
\hline 9,52 & $10-40$ & $30-60$ & $50-85$ \\
\hline 4,76 & $0-5$ & $0-10$ & $0-10$ \\
\hline
\end{tabular}

Sumber : SNI 03-2834-2000

\section{Kuat Tekan Beton}

Nilai kuat tekan beton didapat dari pengujian standar dengan benda uji yang lazim digunakan berbentuk silinder. Dimensi benda uji standar adalah tinggi $300 \mathrm{~mm}$, diameter $150 \mathrm{~mm}$. Tata cara pengujian yang umumnya dipakai adalah standar ASTM C39-86. Kuat tekan masing-masing benda uji ditentukan oleh tegangan tekan tertinggi $\left(f_{c}{ }^{\prime}\right)$ yang dicapai benda uji umur 28 hari akibat beban tekan selama percobaan (Dipohusodo, 1996).

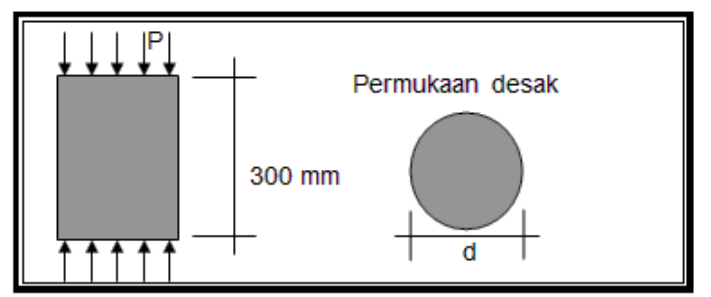

Gambar 1. Pengetesan Kuat Tekan Benda Uji beton
Rumus yang digunakan dalam menentukan nilai kuat tekan beton adalah :

$\mathrm{K}=\frac{P}{A}$

Dimana :

$\mathrm{K}=$ Kuat tekan beton $\left(\mathrm{kg} / \mathrm{cm}^{2}\right)$.

$\mathrm{P}=$ Beban hancur $(\mathrm{kN})$.

$\mathrm{A}=$ Luas silinder $\left(\mathrm{cm}^{2}\right)$.

\section{Kuat Tarik Belah Beton}

Kuat tarik belah adalah kuat tarik beton yang ditentukan berdasarkan kuat tekan belah dari silinder beton yang ditekan pada sisi panjangnya. Kekuatan tarik belah beton relatif rendah, nilai kuat tekan dan tarik belah beton tidak berbanding lurus. Setiap usaha perbaikan mutu kekuatan tekan hanya disertai peningkatan kecil nilai kuat tariknya. Kekuatan tarik yang tepat lebih sulit diukur dibandingkan dengan kekuatan tekan karena masalah penjepitan pada mesin. Ada sejumlah metode yang tersedia untuk menguji kekuatan tarik dan yang paling sering digunakan adalah tes pembelahan silinder atau tes brasil.

Konstruksi beton yang dipasang mendatar sering menerima beban tegak lurus sumbu bahannya dan sering mengalami rekahan (splitting). Hal ini terjadi karena daya dukung beton terhadap gaya lentur tergantung pada jarak dari garis berat beton, makin jauh dari garis berat beton maka makin kecil daya dukungnya. Kuat tarik beton juga ditentukan melalui pengujian split cylinder yang umumnya memberikan hasil yang lebih baik dan lebih mencerminkan kuat tarik yang sebenarnya. Kekuatan tarik belah beton relatif rendah, untuk beton normal berkisar antara 9\% sampai 15\% dari kuat tekan (Istimawan Dipohusodo, 1994).

Pengujian tersebut menggunakan benda uji silinder beton berdiameter $150 \mathrm{~mm}$ dan panjang 300 $\mathrm{mm}$, diletakkan pada arah memanjang di atas alat penguji kemudian beban tekan diberikan merata arah tegak dari atas pada seluruh panjang silinder. Apabila kuat tarik terlampaui, benda uji terbelah menjadi dua bagian dari ujung ke ujung. Tegangan tarik yang timbul sewaktu benda uji terbelah disebut sebagai split cylinder strength.

Berdasarkan SNI 03-2491-2002, nilai kuat tarik belah dapat dihitung dengan perhitungan :

$\mathrm{fct}=\frac{2 \mathrm{P}}{\pi \mathrm{LD}}$

Dimana :

fct $=$ Kuat tarik belah $(\mathrm{MPa})$

$\mathrm{P}=$ Beban pada waktu belah $(\mathrm{N})$

$\mathrm{L}=$ Panjang benda uji silinder $(\mathrm{mm})$

$\mathrm{D}=$ Diameter benda uji silinder $(\mathrm{mm})$ 


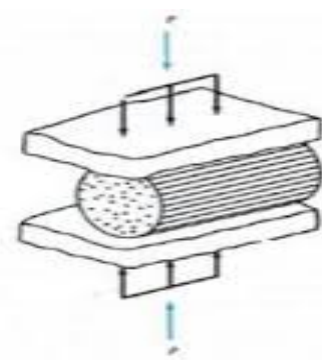

Gambar 2. Penampang Uji Tarik Belah Beton

\section{Setting Time (Berdasarkan ASTM C 1117 - 89)}

Waktu ikat (setting time) adalah waktu yang dibutuhan melakukan proses hidrolis dimana hingga satu waktu tertentu, beton tersebut sudah memiliki kekuatan tertentu pula. ASTM menetapkan bahwa waktu yang dibutuhkan beton agar memiliki kuat desak 500 Psi disebut sebagai Initial Setting Time. Sedangkan waktu yang dibutuhkan pasta beton memiliki kekuatan desak 4.000 Psi disebut sebagai Final Setting Time.

\section{Perencanaan Campuran Beton (Mix Design)}

Mix design merupakan rencana campuran adukan beton untuk mengetahui jumlah kebetuhan material sesuai dengan kekuatan rencana. Setelah pengujian bahan khususnya agregat kasar dan agregat halus, hasil pengujian dapat dimasukkan dalam membuat mix design. Mix design yang dibuat dalam penelitian ini berdasarkan "Tata Cara Pembuatan Beton Normal" mengacu pada SNI 032834-2000 ${ }^{10}$.

\section{Slump Test}

Nilai slump digunakan untuk pengukuran terhadap tingkat kelecekan suatu adukan beton, yang berpengaruh pada tingkat pengerjaan beton (workability). Semakin besar nilai slump maka beton semakin encer dan semakin mudah untuk dikerjakan, sebaliknya semakin kecil nilai slump, maka beton akan semakin kental dan semakin sulit untuk dikerjakan. Slump pada dasarnya salah satu pengetesan sederhana untuk mengetahui workability beton segar sebelum dterima dan diaplikasikan dalam pekerjaan pengecoran. Pengukuran Slump mengacu pada aturan yang ditetapkan dalam SNI 1972-2013 ${ }^{11}$ (Cara Uji Slump Beton).

Pengukuran Slumpt Test berdasarkan peraturan ini dilakukan dengan alat sebagai berikut (ASTM C143)

Tabel 3. Kategori Nilai Slump Test

\begin{tabular}{|c|c|c|}
\hline Keterangan & $\begin{array}{c}\text { Nilai Slump } \\
(\mathbf{m m})\end{array}$ & $\begin{array}{c}\text { Air Yang Diperlukan } \\
(\mathbf{\%})\end{array}$ \\
\hline Sangat Kering & - & 78 \\
\hline Sangat Keras & - & 83 \\
\hline Keras & $0-30$ & 88 \\
\hline Agak Plastis & $30-80$ & 92 \\
\hline Plastis & $80-130$ & 100 \\
\hline Encer & $130-180$ & 106 \\
\hline
\end{tabular}

Sumber : buku referensi "Propeties of Concrete" oleh AM Neville

\section{Metodologi Penelitian}

Secara garis besar tahapan kegiatan penelitian dapat di kelompokkan menjadi tiga tahapan yaitu : tahap persiapan, tahap pelaksanaan pengujian laboratorium, tahap analisis data dan pembuatan laporan hasil. berikut:

Penjelasan langkah-langkah penelitian sebagai

A. Tahap Persiapan

1. Studi Literatur

Pada tahap ini dilakukan pencarian referensi-referensi penelitian yang berhubungan dengan penelitian yang akan dilaksanakan.

2. Persiapan Alat dan Material Mengajukan permohonan melakukan pembuatan dan pengujian beton di PT. Waskita Beton Precast.

B. Tahap Pelaksanaan

1. Pembuatan Sampel Penelitian

Pembuatan sampel untuk penelitian sebanyak 10 sampel untuk variasi campuran kadar fly ash Bangka dengan fly ash Suralaya sebesar 0\%, 10\% dari berat semen dan cacahan karet $5 \%$ dari berat agregat halus dengan silica fume $4 \%$ dari berat semen yang sudah dikurangi dengan berat fly ash dan ditambah dengan superplasticizer sebesar $2 \%$ dari kebutuhan air.

2. Pelaksanaan Pengujian dan Pengumpulan Data

Tahap ini merupakan tahap melakukan pengujian tiap sampel yang sudah dibuat yang kemudian dicatat hasilnya.

Dengan pengujian pada umur 7 hari, 14 hari dan 28 hari

C. Tahap Analisa

Setelah didapatkan data hasil pengujian kemudian dilakukan analisa dan pembahasan serta membandingkan hasil beton tanpa fly ash dengan fly ash Bangka dan fly ash Suralaya dengan bahan admixture terhadap slump test, suhu beton segar, kuat tekan beton dan kuat tarik belah beton, serta setting timenya

\section{Analisis Dan Pembahasan}

\section{Pengujian Fly Ash}

Klasifikasi fly ash berdasarkan hasil pengujian parameter fly ash dari PLTU Bangka masuk katergori jenis $\mathrm{C}$ dimana nilai $\mathrm{SiO} 2+\mathrm{Al} 2 \mathrm{O} 3+$ $\mathrm{Fe} 2 \mathrm{O} 3>50$ sedangkan fly ash dari PLTU Suralaya termasuk Kelas F. > 70 dapat dilihat pada Tabel 4. 
Tabel 4. Hasil Pengujian Parameter Fly Ash

\begin{tabular}{|c|l|c|c|}
\hline No. & \multicolumn{1}{|c|}{$\begin{array}{c}\text { Fly Ash Analysis } \\
\text { Parameter }\end{array}$} & Bangka & Suralaya \\
\cline { 3 - 4 } & \multicolumn{1}{|c|}{$\%$} & $\%$ \\
\hline 1 & Silicon dioxide : SiO2 & 35,74 & 52,67 \\
\hline 2 & $\begin{array}{l}\text { Aluminium Oxide : } \\
\text { Al2O3 }\end{array}$ & 12,01 & 22,52 \\
\hline 3 & Ferric Oxide : Fe2O3 & 19,32 & 8,94 \\
\hline 4 & Sulfur Trioxide : SO3 & $3,13<5$ & $0,81<5$ \\
\hline 5 & $\begin{array}{l}\text { Magnesium Oxide : } \\
\text { MgO }\end{array}$ & $1,76<6$ & $3,86<6$ \\
\hline 6 & $\begin{array}{l}\text { SiO2 + Al2O3 + } \\
\text { Fe2O3 }\end{array}$ & $67,07>50$ & $84,13>70$ \\
\hline 7 & ASTM 618-2012 & Jenis C & Jenis F \\
\hline 8 & Loss on Ignitio (LOI) & $0,68<6$ & $3,32<6$ \\
\hline
\end{tabular}

Sumber : Hasil Pengolahan Data

\section{Pengujian Agregat Halus/Pasir}

Dalam penelitian ini menggunakan dua variasi pasir dari Belitung dan pasir dari Cimalaya, yang mempunyai karakteristis yang berbeda seperti dari hasil pengujian di bawah ini. Dimana pasir Belitung kandungan organis tinggi sehingga memperlama pengikatan beton sedangkan pasir Cimalaya mempunyai gradasi agak halus.

\section{a. Agregat Halus Pasir Belitung}

Modulus kehalusan pasir Belitung yaitu $2,184 \%$ termasuk mempunyai tingkat kehalusan pasir halus dan memenuhi syarat yang ditetapkan dalam SNI 03-6820-2002 ${ }^{12}$ yakni dengan modulus kehalusan pasir $1,50 \%-3,80 \%$.

Tabel 5. Hasil Pengujian Analisis Gradasi Pasir Belitung

\begin{tabular}{|c|c|c|c|c|c|c|c|c|c|c|}
\hline \multicolumn{2}{|c|}{2} & \multicolumn{3}{|c|}{ Sampel 1} & \multicolumn{3}{|c|}{ Sampel 2} & \multicolumn{3}{|c|}{ Average } \\
\hline $\mathrm{mm}$ & No & $\begin{array}{l}\text { Berat } \\
\text { gram }\end{array}$ & $\begin{array}{c}\% \\
\text { Tertinggal }\end{array}$ & $\begin{array}{c}\% \\
\text { Komulatif }\end{array}$ & $\begin{array}{l}\text { Berat } \\
\text { gram }\end{array}$ & $\begin{array}{c}\% \\
\text { Tertinggal }\end{array}$ & $\begin{array}{c}\% \\
\text { Komulatif }\end{array}$ & $\begin{array}{c}\% \\
\text { Tertinggal }\end{array}$ & $\begin{array}{c}\% \\
\text { Komulatif }\end{array}$ & $\begin{array}{c}\% \\
\text { Total }\end{array}$ \\
\hline 9,50 & $3 / 8^{\prime \prime}$ & 0 & 0 & 0 & 0 & 0 & 0 & 0 & 0 & 100 \\
\hline 4,75 & 4 & 0 & 0 & 0 & 0 & 0 & 0 & 0 & 0 & 100 \\
\hline 2,36 & 8 & 11 & 2,2 & 2,2 & 8 & 1,6 & 1,6 & 1,9 & 1,9 & 98,1 \\
\hline 1,18 & 16 & 38 & 7,6 & 9,8 & 41 & 8,2 & 9,8 & 7,9 & 9,8 & 90,2 \\
\hline 0,60 & 30 & 160 & 32 & 41,8 & 165 & 33,0 & 42,8 & 32,5 & 42,3 & 57,7 \\
\hline 0,30 & 50 & 132 & 26,4 & 68,2 & 131 & 26,2 & 69,0 & 26,3 & 68,6 & 31,4 \\
\hline 0,15 & 100 & 137 & 27,4 & 95,6 & 135 & 27,0 & 96,0 & 27,2 & 95,8 & 4,2 \\
\hline \multicolumn{2}{|c|}{ Pan } & 22 & 4,4 & 100 & 20 & 4,0 & 100 & 4,2 & 100 & 0 \\
\hline \multicolumn{2}{|c|}{ Total } & 500 & 100 & & 500 & 100 & & 100 & & \\
\hline
\end{tabular}

Sumber : Hasil Pengolahan Data

Tabel 6. Batas dan Hasil Pengujian Gradasi Pasir Belitung

\begin{tabular}{|c|c|c|c|c|c|}
\hline \multirow{2}{*}{$\begin{array}{c}\text { Lubang } \\
\text { Ayakan } \\
(\mathbf{m m})\end{array}$} & $\begin{array}{c}\text { Kasar } \\
(\text { Zona } \\
\text { I) }\end{array}$ & $\begin{array}{c}\text { Agak } \\
\text { Kasar } \\
\text { (Zona II) }\end{array}$ & $\begin{array}{c}\text { Agak } \\
\text { Halus } \\
\text { (Zona III) }\end{array}$ & $\begin{array}{c}\text { Halus } \\
\text { (Zona } \\
\text { IV) }\end{array}$ & $\begin{array}{c}\text { Pasir } \\
\text { Belitung }\end{array}$ \\
\hline 9,50 & 100 & $\mathbf{1 0 0}$ & 100 & 100 & $\mathbf{1 0 0}$ \\
\hline 4,75 & $\begin{array}{c}90- \\
100\end{array}$ & $\mathbf{9 0}-\mathbf{1 0 0}$ & $90-100$ & $95-100$ & $\mathbf{1 0 0}$ \\
\hline 2,36 & $60-95$ & $\mathbf{7 5}-\mathbf{1 0 0}$ & $85-100$ & $95-100$ & $\mathbf{9 8 , 1}$ \\
\hline 1,18 & $30-75$ & $\mathbf{5 5}-\mathbf{9 0}$ & $75-100$ & $90-100$ & $\mathbf{9 0 , 2}$ \\
\hline 0,60 & $15-34$ & $\mathbf{3 3}-\mathbf{5 9}$ & $60-79$ & $80-100$ & $\mathbf{5 7 , 7}$ \\
\hline 0,30 & $5-20$ & $\mathbf{8}-\mathbf{3 0}$ & $12-40$ & $15-100$ & $\mathbf{3 1 , 4}$ \\
\hline 0,15 & $0-10$ & $\mathbf{0}-\mathbf{1 0}$ & $0-10$ & $0-15$ & $\mathbf{4 , 2}$ \\
\hline
\end{tabular}

Hasil analisa gradasi pasir Belitung termasuk zona 2 yaitu masuk kategori pasir agak kasar seperti terlihat pada Gambar 3 dan Tabel 6.

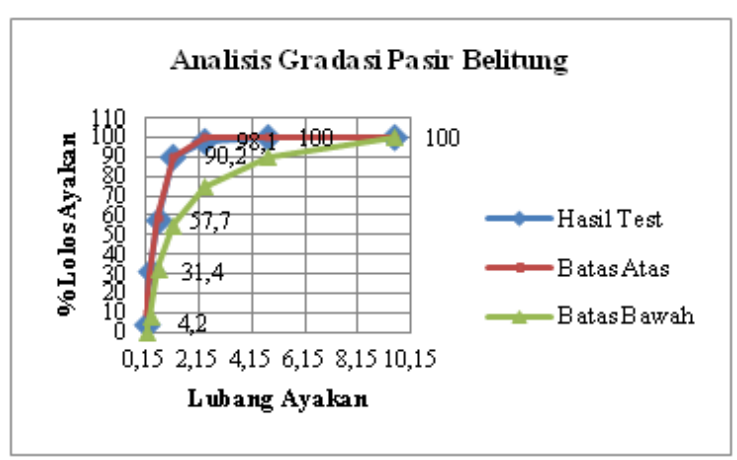

Gambar 3. Grafik Pengujian Analisis Gradasi Pasir Belitung

\section{Kandungan Lumpur Dalam Pasir Belitung}

Kandungan lumpur pada pasir Bangka ratarata sebesar $1,7 \%$. Kandungan lumpur dalam pasir ini memenuhi syarat yang ditetapkan menurut SNI 03-6820-2002 yakni kandungan lumpur dalam pasir sebanyak $5 \%$. 
Tabel 7. Hasil Data Kandungan Lumpur Dalam Pasir Belitung

\begin{tabular}{|c|l|c|c|}
\hline No. & \multicolumn{1}{|c|}{ Keterangan } & $\begin{array}{c}\text { Sample } \\
\text { I }\end{array}$ & $\begin{array}{c}\text { Sample } \\
\text { II }\end{array}$ \\
\hline A & Berat pasir (S) & $500 \mathrm{gr}$ & $500 \mathrm{gr}$ \\
\hline B & $\begin{array}{l}\text { Berat pasir setelah } \\
\text { dikeringkan }(\mathrm{A})\end{array}$ & $493 \mathrm{gr}$ & $490 \mathrm{gr}$ \\
\hline C & $\begin{array}{l}\text { Kadar lumpur } \\
\text { pasir }\left(\frac{S-A}{S} x 100 \%\right)\end{array}$ & $1,4 \%$ & $2,0 \%$ \\
\hline Rata - rata kadar lumpur pasir & \multicolumn{2}{|c|}{$1,7 \%$} \\
\hline
\end{tabular}

Sumber : Hasil Pengolahan Data

\section{Kandungan Organis Dalam Pasir Belitung}

Berdasarkan hasil pengujian kandungan organis dalam pasir, hasil yang didapatkan pada pembacaan picmen colour adalah warna coklat Gelap. Dimana arti dari warna ini mengindikasikan kandungan organik dalam pasir sangat banyak.

Tabel 8. Hasil Data Kandungan Organis Dalam Pasir Belitung

\begin{tabular}{|c|l|l|}
\hline $\begin{array}{l}\text { Warna Pasir Setelah di Tambah } \\
\text { Larutan NaoH }\end{array}$ & \multicolumn{2}{|l|}{ Form Warna } \\
\hline \multirow{5}{*}{$\begin{array}{c}\text { Bening / Sama Dengan / } \\
\text { Lebih Gelap dari }\end{array}$} & 1. Jernih & \\
\hline & $\begin{array}{l}\text { 2. Jernih Kuning } \\
\text { (Standar) }\end{array}$ & \\
\cline { 2 - 3 } & 4. Coklat & \\
\hline & 5. Coklat Gelap & $\mathrm{v}$ \\
\hline
\end{tabular}

Sumber : Hasil Pengolahan Data

Berat Jenis Pasir Belitung dan Penyerapan Air

Berdasarkan hasil pengujian berat jenis pasir dan penyerapan air menunjukkan bahwa rata-rata berat jenis kering pasir Bangka yang didapatkan dalam pengujian sebesar 2,60. Untuk rata-rata berat jenis dalam kondisi SSD (Saturated Surface Dry) yang didapatkan sebesar 2,632. Sedangkan, ratarata hasil pengujian penyerapan air sebesar 1,215 $\%$.

Tabel 9. Hasil Data Berat Jenis Pasir Belitung dan Penyerapan Air

\begin{tabular}{|c|c|c|c|}
\hline No. & Keterangan & $\begin{array}{l}\text { Sample } \\
\text { I }\end{array}$ & $\begin{array}{l}\text { Sample } \\
\text { II }\end{array}$ \\
\hline A & Berat pasir (S) & $500 \mathrm{gr}$ & $500 \mathrm{gr}$ \\
\hline $\mathrm{B}$ & $\begin{array}{l}\text { Berat pasir setelah dikeringkan } \\
\text { (A) }\end{array}$ & $495 \mathrm{gr}$ & $493 \mathrm{gr}$ \\
\hline $\mathrm{C}$ & Berat air + piknometer $(\mathrm{B})$ & $660 \mathrm{gr}$ & $661 \mathrm{gr}$ \\
\hline $\mathrm{D}$ & $\begin{array}{l}\text { Berat piknometer + 500gr pasir } \\
+ \text { air }(\mathrm{C})\end{array}$ & $971 \mathrm{gr}$ & $970 \mathrm{gr}$ \\
\hline $\mathrm{E}$ & Berat jenis kering $\left(\frac{A}{(B+S)-C}\right)$ & 2,619 & 2,581 \\
\hline $\mathrm{F}$ & $\begin{array}{l}\text { Saturated Surface Dry } \\
(\mathrm{SSD})\left(\frac{S}{(B+S)-C}\right)\end{array}$ & 2,646 & 2,681 \\
\hline G & $\%$ Penyerapan $\left(\frac{S-A}{A} x 100 \%\right)$ & $\begin{array}{c}1,010 \\
\%\end{array}$ & $1,420 \%$ \\
\hline $\mathrm{H}$ & Rata - rataberat jenis kering & \multicolumn{2}{|c|}{2,600} \\
\hline I & $\begin{array}{l}\text { Rata - rata Saturated Surface } \\
\text { Dry (SSD) }\end{array}$ & \multicolumn{2}{|c|}{2,632} \\
\hline $\mathrm{J}$ & Rata - rata $\%$ penyerapan & \multicolumn{2}{|c|}{$1,215 \%$} \\
\hline
\end{tabular}

Sumber : Hasil Pengolahan Data

\section{b. Pengujian Agregat Halus/Pasir Cimalaka}

Modulus kehalusan pasir Cimalaka yaitu 2,758 $\%$ termasuk mempunyai tingkat kehalusan pasir sedang dan memenuhi syarat yang ditetapkan dalam SNI 03-6820-2002 ${ }^{11}$ yakni dengan modulus kehalusan pasir $1,50 \%-3,80 \%$

Tabel 10. Hasil Pengujian Analisis Gradasi Pasir Cimalaka

\begin{tabular}{|c|c|c|c|c|c|c|c|c|c|c|}
\hline \multicolumn{2}{|c|}{ Lubang Ayakan } & \multicolumn{3}{|c|}{ Sampel 1} & \multicolumn{3}{|c|}{ Sampel 2} & \multicolumn{3}{|c|}{ Average } \\
\hline $\mathrm{mm}$ & No & $\begin{array}{l}\text { Berat } \\
\text { gram }\end{array}$ & $\begin{array}{c}\% \\
\text { Tertingga } \\
1\end{array}$ & $\begin{array}{c}\% \\
\text { komulatif }\end{array}$ & $\begin{array}{l}\text { Berat } \\
\text { gram }\end{array}$ & $\begin{array}{c}\% \\
\text { Tertinggal }\end{array}$ & $\begin{array}{c}\% \\
\text { komulatif }\end{array}$ & $\begin{array}{c}\% \\
\text { Tertinggal }\end{array}$ & $\begin{array}{c}\% \\
\text { komulatif }\end{array}$ & $\begin{array}{c}\% \\
\text { Total }\end{array}$ \\
\hline 9,50 & $3 / 8^{\prime \prime}$ & 0 & 0 & 0 & 0 & 0 & 0 & 0 & 0 & 100 \\
\hline 4,75 & 4 & 0 & 0 & 0 & 0 & 0 & 0 & 0 & 0 & 100 \\
\hline 2,36 & 8 & 97 & 19,4 & 19,4 & 92 & 18,4 & 18,4 & 18,9 & 18,9 & 88,1 \\
\hline 1,18 & 16 & 95 & 19,0 & 38,4 & 97 & 19,4 & 37,8 & 19,2 & 38,1 & 61,9 \\
\hline 0,60 & 30 & 117 & 23,4 & 61,8 & 116 & 23,2 & 61,0 & 23,3 & 61,4 & 38,6 \\
\hline 0,30 & 50 & 54 & 10,8 & 72,6 & 55 & 11,0 & 72,0 & 10,9 & 72,3 & 27,7 \\
\hline 0,15 & 100 & 64 & 12,8 & 85,4 & 64 & 12,8 & 84,8 & 12,8 & 85,1 & 14,9 \\
\hline \multicolumn{2}{|c|}{ Pan } & 73 & 14,6 & 100 & 76 & 15,2 & 100 & 14,9 & & 0 \\
\hline \multicolumn{2}{|c|}{ Total } & 500 & 100 & & 500 & 100 & & 100 & 275,8 & \\
\hline \multicolumn{9}{|c|}{ FM : Modulus Kehalusan Pasir $=\frac{\text { Jumlah } \% \text { komulatif yang tertinggal }}{100}$} & \multicolumn{2}{|l|}{$=2,758 \%$} \\
\hline
\end{tabular}

Sumber : Hasil Pengolahan Data 
Tabel 11. Batas dan Hasil Pengujian Gradasi Pasir Cimalaka

\begin{tabular}{|c|c|c|c|c|c|}
\hline \multirow{2}{*}{$\begin{array}{c}\text { Lubang } \\
\text { Ayakan } \\
(\mathbf{m m})\end{array}$} & $\begin{array}{c}\text { Kasar } \\
\text { (Zona I) }\end{array}$ & $\begin{array}{c}\text { Agak } \\
\text { Kasar } \\
\text { (Zona } \\
\text { II) }\end{array}$ & $\begin{array}{c}\text { Agak } \\
\text { Halus } \\
\text { (Zona III) }\end{array}$ & $\begin{array}{c}\text { Halus } \\
\text { (Zona } \\
\text { IV) }\end{array}$ & $\begin{array}{c}\text { Pasir } \\
\text { Cimal } \\
\text { aka }\end{array}$ \\
\hline 9,50 & 100 & $\mathbf{1 0 0}$ & $\mathbf{1 0 0}$ & 100 & $\mathbf{1 0 0}$ \\
\hline 4,75 & $90-$ & $90-$ & $\mathbf{9 0}-\mathbf{1 0 0}$ & $\begin{array}{c}95- \\
100\end{array}$ & $\mathbf{1 0 0}$ \\
\hline 2,36 & $60-95$ & $\begin{array}{c}75- \\
100\end{array}$ & $\mathbf{8 5}-\mathbf{1 0 0}$ & $\begin{array}{c}95- \\
100\end{array}$ & $\mathbf{8 8 , 1}$ \\
\hline 1,18 & $30-75$ & $55-90$ & $\mathbf{7 5}-\mathbf{1 0 0}$ & $\begin{array}{c}90- \\
100\end{array}$ & $\mathbf{6 1 , 9}$ \\
\hline 0,60 & $15-34$ & $33-59$ & $\mathbf{6 0}-\mathbf{7 9}$ & $\begin{array}{c}80- \\
100\end{array}$ & $\mathbf{3 8 , 6}$ \\
\hline 0,30 & $5-20$ & $8-30$ & $\mathbf{1 2}-\mathbf{4 0}$ & $\begin{array}{c}15- \\
100\end{array}$ & $\mathbf{2 7 , 7}$ \\
\hline 0,15 & $0-10$ & $0-10$ & $\mathbf{0}-\mathbf{1 0}$ & $0-15$ & $\mathbf{1 4 , 9}$ \\
\hline
\end{tabular}

Sumber : SNI 03-2834-2000 dan Hasil Pengolahan Data

Hasil analisa gradasi pasir Cimalaka termasuk zona III yaitu masuk kategori pasir agak halus, seperti terlihat pada Gambar 4 dan Tabel 11.

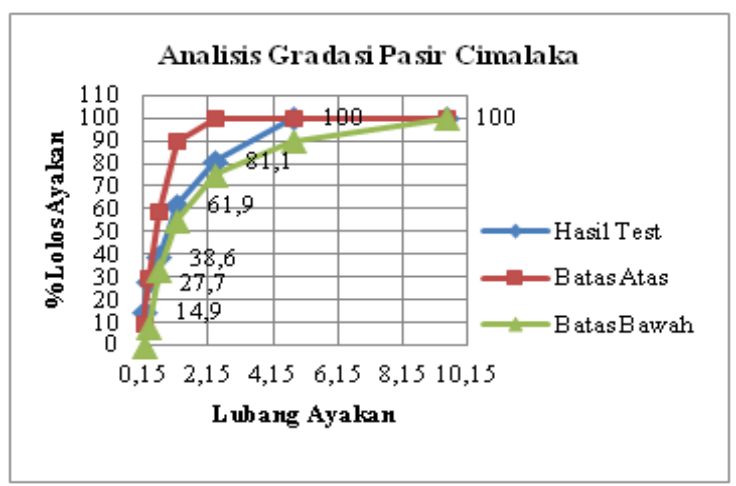

Gambar 4. Grafik Pengujian Analisis Gradasi Pasir Cimalaka

Kandungan Lumpur Dalam Pasir Cimalaka

Kandungan lumpur pada pasir Bangka ratarata sebesar 4,5\%. Kandungan lumpur dalam pasir ini memenuhi syarat yang ditetapkan dalam menurut SNI 03-6820-2002 yakni kandungan lumpur dalam pasir sebanyak $5 \%$.

Tabel 12. Hasil Data Kandungan Lumpur Dalam Pasir Cimalaka

\begin{tabular}{|c|l|c|c|}
\hline No. & \multicolumn{1}{|c|}{ Keterangan } & Sample I & $\begin{array}{c}\text { Sample } \\
\text { II }\end{array}$ \\
\hline A & Berat pasir (S) & $500 \mathrm{gr}$ & $500 \mathrm{gr}$ \\
\hline B & $\begin{array}{l}\text { Berat pasir setelah } \\
\text { dikeringkan (A) }\end{array}$ & $480 \mathrm{gr}$ & $475 \mathrm{gr}$ \\
\hline C & $\begin{array}{l}\text { Kadar lumpur } \\
\text { pasir }\left(\frac{S-A}{S} x 100 \%\right)\end{array}$ & $4 \%$ & $5 \%$ \\
\hline \multicolumn{2}{|l|}{ Rata - rata kadar lumpur pasir } & \multicolumn{2}{|c|}{$4,5 \%$} \\
\hline
\end{tabular}

Sumber : Hasil Pengolahan Data

Kandungan Organis Dalam Pasir Cimalaka
Berdasarkan hasil pengujian kandungan organis dalam pasir, hasil yang didapatkan pada pembacaan picmen colour adalah warna jernih kuning. Dimana arti dari warna ini mengindikasikan kandungan organik dalam pasir sangat sedikit.

Tabel 13. Hasil Data Kandungan Organis Dalam Pasir Cimalaka

\begin{tabular}{|c|c|c|}
\hline 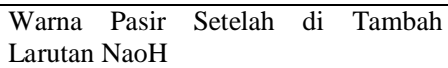 & \multicolumn{2}{|c|}{ Form Warna } \\
\hline \multirow{5}{*}{$\begin{array}{c}\text { Bening / Sama Dengan / } \\
\text { Lebih Gelap dari }\end{array}$} & 1. Jernih & \\
\hline & $\begin{array}{l}\text { 2. Jernih } \\
\text { Kuning }\end{array}$ & $\mathrm{v}$ \\
\hline & $\begin{array}{l}\text { 3. Kuning } \\
\text { (Standar) }\end{array}$ & \\
\hline & 4. Coklat & \\
\hline & $\begin{array}{l}\text { 5. Coklat } \\
\text { Gelap }\end{array}$ & \\
\hline
\end{tabular}

Sumber : Hasil Pengolahan Data

\section{Berat Jenis Pasir Cimalaka dan Penyerapan Air}

Berdasarkan hasil pengujian berat jenis pasir dan penyerapan air menunjukkan bahwa rata-rata berat jenis kering pasir Cimalaka yang didapatkan dalam pengujian sebesar 2,689. Untuk rata-rata berat jenis dalam kondisi SSD (Saturated Surface Dry) yang didapatkan sebesar 2,732. Sedangkan, rata-rata hasil pengujian penyerapan air sebesar $1,626 \%$

Tabel 14. Hasil Data Berat Jenis Pasir Cimalaka dan Penyerapan Air

\begin{tabular}{|c|l|c|c|}
\hline No. & \multicolumn{1}{|c|}{ Keterangan } & $\begin{array}{c}\text { Sample } \\
\text { I }\end{array}$ & Sample II \\
\hline A & Berat pasir (S) & $500 \mathrm{gr}$ & $500 \mathrm{gr}$ \\
\hline B & Berat pasir setelah dikeringkan (A) & $492 \mathrm{gr}$ & $492 \mathrm{gr}$ \\
\hline C & Berat air + piknometer (B) & $670 \mathrm{gr}$ & $673 \mathrm{gr}$ \\
\hline D & $\begin{array}{l}\text { Berat piknometer }+500 \mathrm{gr} \text { pasir }+ \\
\text { air }(\mathrm{C})\end{array}$ & $987 \mathrm{gr}$ & $990 \mathrm{gr}$ \\
\hline E & Berat jenis kering $\left(\frac{A}{(B+S)-C}\right)$ & 2,689 & 2,689 \\
\hline F & $\begin{array}{l}\text { Saturated Surface Dry } \\
(\text { SSD })\left(\frac{S}{(B+S)-C}\right)\end{array}$ & 2,732 & 2,732 \\
\hline G & $\%$ Penyerapan $\left(\frac{S-A}{A} x 100 \%\right)$ & $1,626 \%$ & $1,626 \%$ \\
\hline H & Rata - rataberat jenis kering & \multicolumn{2}{|c|}{2,689} \\
\hline I & $\begin{array}{l}\text { Rata }- \text { rata Saturated Surface Dry } \\
(\text { SSD })\end{array}$ & \multicolumn{2}{|c|}{2,732} \\
\hline J & Rata - rata $\%$ penyerapan & \multicolumn{2}{|c|}{$1,626 \%$} \\
\hline
\end{tabular}

Sumber : Hasil Pengolahan Data

\section{Pengujian Agregat Kasar/Kerikil}

a. Analisa Agregat Kasar/Kerikil

Berdasarkan hasil dari pengujian analisis gradasi kerikil Rumpin menunjukkan bahwa hasil untuk modulus kehalusan yang didapat sebesar $3,291 \%$. Nilai modulus kehalusan ini, memenuhi syarat menurut SNI 03-2461-2002 yaitu modulus kehalusan kerikil $6 \%-7,1 \%$. 
Tabel 15. Hasil Pengujian Analisis Gradasi Kerikil

\begin{tabular}{|c|c|c|c|c|c|c|c|c|c|}
\hline \multirow[b]{2}{*}{$\begin{array}{l}\text { Ukuran Ayakan } \\
(\mathrm{mm})\end{array}$} & \multicolumn{3}{|c|}{ Sampel 1} & \multicolumn{3}{|c|}{ Sampel 2} & \multicolumn{3}{|c|}{ Rata - Rata } \\
\hline & $\begin{array}{c}\text { Berat } \\
\text { tertinggal } \\
(\mathrm{gr}) \\
\end{array}$ & $\begin{array}{c}\% \\
\text { tertinggal }\end{array}$ & $\begin{array}{c}\% \\
\text { komulatif }\end{array}$ & $\begin{array}{c}\text { Berat } \\
\text { tertinggal } \\
(\mathrm{gr})\end{array}$ & $\begin{array}{c}\% \\
\text { tertinggal }\end{array}$ & $\begin{array}{c}\% \\
\text { komulatif }\end{array}$ & $\begin{array}{c}\% \\
\text { tertinggal }\end{array}$ & $\begin{array}{c}\% \\
\text { komulatif }\end{array}$ & $\begin{array}{c}\% \\
\text { Total }\end{array}$ \\
\hline 38,10 & 0 & 0 & 0 & 0 & 0 & 0 & 0 & 0 & 100 \\
\hline 25,40 & 176 & 3,52 & 3,52 & 200 & 4 & 4 & 3,76 & 3,76 & 96,24 \\
\hline 19,00 & 2140 & 42,80 & 46,32 & 1986 & 39,72 & 43,72 & 41,26 & 45,02 & 54,98 \\
\hline 12,50 & 2012 & 40,24 & 86,56 & 2115 & 42,3 & 86,02 & 41,27 & 86,29 & 13,71 \\
\hline 9,50 & 410 & 8,20 & 94,76 & 425 & 8,5 & 94,52 & 8,35 & 94,64 & 5,36 \\
\hline 4,76 & 234 & 4,68 & 99,44 & 241 & 4,82 & 99,34 & 4,75 & 99,39 & 0,61 \\
\hline PAN & 28 & 0,56 & 100 & 33 & 0,66 & 100 & 0,61 & & 0 \\
\hline Total & 5000 & 100 & & 5000 & 100 & & 100 & 329,1 & \\
\hline FM : Modulus K & n Kerik & nlah \% ko & atif yang te & & & & & & 3,291 \\
\hline
\end{tabular}

Sumber : Hasil Pengolahan Data

Tabel 16. Syarat Batas dan Hasil Gradasi Kerikil

\begin{tabular}{|c|c|c|c|c|}
\hline \multirow{3}{*}{$\begin{array}{c}\text { Ukuran } \\
\text { Lubang } \\
\text { Ayakan } \\
(\mathrm{mm})\end{array}$} & \multicolumn{4}{|c|}{ Persentase Berat Bagian Yang Lewat Ayakan } \\
\hline & \multicolumn{3}{|c|}{ Ukuran Nominal Agregat (mm) } & $\begin{array}{c}\text { Hasil } \\
\text { Gradasi } \\
\text { Kerikil }\end{array}$ \\
\hline & 40 & 20 & 10 & 40 \\
\hline 38,1 & $95-100$ & 100 & - & 100 \\
\hline 19,0 & $37-70$ & $95-100$ & 100 & 54,98 \\
\hline 9,52 & $10-40$ & $30-60$ & $50-85$ & 13,71 \\
\hline 4,76 & $0-5$ & $0-10$ & $0-10$ & $\mathbf{0 , 6 1}$ \\
\hline
\end{tabular}

Sumber : SNI 03-2834-2000 dan Hasil Pengolahan Data

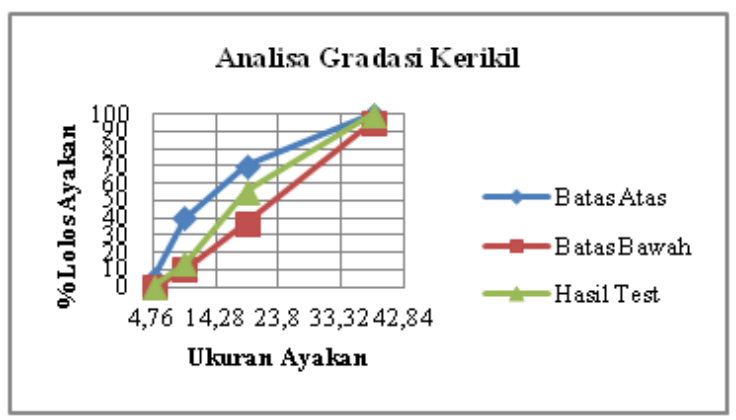

Gambar 5. Gradasi Kerikil

\section{b. Kandungan Lumpur Dalam Kerikil}

Kandungan lumpur dalam kerikil Rumpin rata-rata sebesar $1,75 \%$. Hasil ini berarti menunjukkan nilai kadar lumpur lebih dari $1 \%$ maka kerikil harus dicuci terlebih dahulu sebelum digunakan.

Tabel 17. Hasil Data Kandungan Lumpur Dalam Kerikil

\begin{tabular}{|c|l|c|c|}
\hline No. & \multicolumn{1}{|c|}{ Keterangan } & Sample I & Sample II \\
\hline A & Berat kerikil (S) & $1000 \mathrm{gr}$ & $1000 \mathrm{gr}$ \\
\hline B & $\begin{array}{l}\text { Berat kerikil setelah } \\
\text { dikeringkan (A) }\end{array}$ & $985 \mathrm{gr}$ & $980 \mathrm{gr}$ \\
\hline $\mathrm{C}$ & $\begin{array}{l}\text { Kadar lumpur kerikil } \\
\left(\frac{S-A}{S} \times 100 \%\right)\end{array}$ & $1,5 \%$ & $2,0 \%$ \\
\hline \multicolumn{2}{|c|}{ Rata - rata kadar lumpur kerikil } & \multicolumn{2}{|c|}{$1,75 \%$} \\
\hline
\end{tabular}

Sumber : Hasil Pengolahan Data c. Berat Jenis Kerikil dan Penyerapan Air

Berdasarkan hasil pengujian berat kerikil dan penyerapan air menunjukkan bahwa rata-rata berat jenis kering kerikil adalah 2,439\% dan untuk ratarata berat jenis kondisi Saturated Surface Dry (SSD) adalah 2,498\% dan penyerapan air sebesar $2,428 \%$.

Tabel 18. Hasil Pengujian Berat Jenis Kerikil dan Penyerapan Air

\begin{tabular}{|c|l|c|c|}
\hline No. & \multicolumn{1}{|c|}{ Keterangan } & $\begin{array}{c}\text { Sample } \\
\text { I }\end{array}$ & $\begin{array}{c}\text { Sample } \\
\text { II }\end{array}$ \\
\hline A & Berat agregat kasar & $5000 \mathrm{gr}$ & $5000 \mathrm{gr}$ \\
\hline B & $\begin{array}{l}\text { Berat agregat kasar setelah } \\
\text { dikeringkan }\end{array}$ & $4880 \mathrm{gr}$ & 4883 \\
\hline C & Berat agregat kasar dalam air & $3000 \mathrm{gr}$ & 2997 \\
\hline D & Berat jenis agregat kasar $\left(\frac{B}{A-C}\right)$ & 2,440 & 2,438 \\
\hline E & $\begin{array}{l}\text { Saturated Surface Dry } \\
\text { (SSD) }\left(\frac{A}{A-C}\right)\end{array}$ & 2,500 & 2,496 \\
\hline F & $\%$ Penyerapan $\left(\frac{A-B}{B} x 100 \%\right)$ & $2.459 \%$ & $2,396 \%$ \\
\hline G & Rata - rataberat jenis kering & \multicolumn{2}{|c|}{$2,439 \%$} \\
\hline H & $\begin{array}{l}\text { Rata }- \text { rata Saturated Surface } \\
\text { Dry }(\text { SSD })\end{array}$ & \multicolumn{2}{|c|}{$2,498 \%$} \\
\hline I & Rata - rata \% penyerapan & \multicolumn{2}{|c|}{$2,428 \%$} \\
\hline
\end{tabular}

Sumber : Hasil Pengolahan Data

\section{Jumlah Kebutuhan Bahan Material Mix design beton}

Proporsi bahan material beton dengan mix design menggunakan metode SNI 03-2834-2000 tersebut dapat dilihat pada table berikut :

Tabel 17. Proporsi campuran adukan beton.

\begin{tabular}{|c|l|l|r|r|}
\hline \multirow{2}{*}{ No } & \multirow{2}{*}{ Material } & \multicolumn{3}{|c|}{ Komposisi Material } \\
\cline { 3 - 5 } & & $\begin{array}{c}\text { No Fly } \\
\text { ash }\end{array}$ & $\begin{array}{c}\text { Fly Ash } \\
\text { Bangka }\end{array}$ & $\begin{array}{c}\text { Fly Ash } \\
\text { Suralaya }\end{array}$ \\
\hline \multirow{2}{*}{1} & Semen & 425,00 & 381,00 & 381,00 \\
& (Indocement) & $\mathrm{kg} / \mathrm{m}^{3}$ & $\mathrm{~kg} / \mathrm{m}^{3}$ & $\mathrm{~kg} / \mathrm{m}^{3}$ \\
\hline \multirow{2}{*}{2} & \multirow{2}{*}{ Flay Ash } & $-\mathrm{kg} / \mathrm{m}^{3}$ & 44,00 & 44,00 \\
& & 29,35 & 29,35 & $\mathrm{~kg} / \mathrm{m}^{3}$ \\
\hline \multirow{2}{*}{3} & \multirow{2}{*}{ Karet } & $\mathrm{kg} / \mathrm{m}^{3}$ & $\mathrm{~kg} / \mathrm{m}^{3}$ & $\mathrm{~kg} / \mathrm{m}^{3}$ \\
\hline 4 & Silicafume & 18,00 & 18,00 & 18,00 \\
\hline
\end{tabular}




\begin{tabular}{|c|c|c|c|c|}
\hline & & $\mathrm{kg} / \mathrm{m}^{3}$ & $\mathrm{~kg} / \mathrm{m}^{3}$ & $\mathrm{~kg} / \mathrm{m}^{3}$ \\
\hline 5 & $\begin{array}{l}\text { Agregat } \\
\text { Kasar } \\
\text { (Rumpin) }\end{array}$ & $\begin{array}{l}999,00 \\
\mathrm{~kg} / \mathrm{m}^{3}\end{array}$ & $\begin{array}{r}999,00 \\
\mathrm{~kg} / \mathrm{m}^{3}\end{array}$ & $\begin{array}{r}999,00 \\
\mathrm{~kg} / \mathrm{m}^{3}\end{array}$ \\
\hline 6 & $\begin{array}{l}\text { Agragat } \\
\text { Halus } \\
\text { (Belitung) }\end{array}$ & $\begin{array}{l}558,00 \\
\mathrm{~kg} / \mathrm{m}^{3}\end{array}$ & $\begin{array}{r}558,00 \\
\mathrm{~kg} / \mathrm{m}^{3}\end{array}$ & $\begin{array}{r}558,00 \\
\mathrm{~kg} / \mathrm{m}^{3}\end{array}$ \\
\hline 7 & $\begin{array}{l}\text { Agregat } \\
\text { Halus } \\
\text { (Cimalaka) }\end{array}$ & $\begin{array}{l}148,00 \\
\mathrm{~kg} / \mathrm{m}^{3}\end{array}$ & $\begin{array}{r}148,00 \\
\mathrm{~kg} / \mathrm{m}^{3}\end{array}$ & $\begin{array}{r}148,00 \\
\mathrm{~kg} / \mathrm{m}^{3}\end{array}$ \\
\hline 8 & $\begin{array}{l}\text { Air (PAM } \\
\text { Aetra) }\end{array}$ & $\begin{array}{l}170,00 \\
\mathrm{~kg} / \mathrm{m}^{3}\end{array}$ & $\begin{array}{r}170,00 \\
\mathrm{~kg} / \mathrm{m}^{3}\end{array}$ & $\begin{array}{r}170,00 \\
\mathrm{~kg} / \mathrm{m}^{3}\end{array}$ \\
\hline 9 & $\begin{array}{l}\text { Admixture } \\
\text { (Plastocrete } \\
\text { RT6+) }\end{array}$ & $1,02 \mathrm{Lt} / \mathrm{m}^{3}$ & $\begin{array}{r}1,02 \\
\mathrm{Lt} / \mathrm{m}^{3}\end{array}$ & $\begin{array}{r}1,02 \\
\mathrm{Lt} / \mathrm{m}^{3}\end{array}$ \\
\hline 10 & $\begin{array}{l}\text { Admixture } \\
\text { Viscocrete } \\
3115 \mathrm{~N}\end{array}$ & $2,21 \mathrm{Lt} / \mathrm{m}^{3}$ & $\begin{array}{r}2,21 \\
\mathrm{Lt} / \mathrm{m}^{3}\end{array}$ & $\begin{array}{r}2,21 \\
\mathrm{Lt} / \mathrm{m}^{3}\end{array}$ \\
\hline
\end{tabular}

Sumber : Hasil Pengolahan Data

\section{Hasil Pengujian Kuat Tekan Beton}

Peningkatan kenaikan kuat tekan beton awal dengan penambahan SF 4\%, SP 2\%, dan Karet 5\% lebih tinggi yang menggunakan fly ash 10\% sampai umur 14 hari, dan umur sampai 28 hari kenaikan nya hanya kecil. Sedangkan beton yang tidak menggunakan fly ash kenaikannya linier dangan bertambahnya umur beton. Hasil pengujian kuat tekan beton semua variasi dapat dilihat pada table 4.17 dan Grafik 4.4

Tabel 18. Hasil Kuat Tekan Semua Variasi

\begin{tabular}{|c|c|c|c|c|c|c|}
\hline $\begin{array}{c}\text { Va- } \\
\text { riasi }\end{array}$ & \multicolumn{2}{|c|}{ No Fly Ash } & \multicolumn{2}{c|}{ Fly Ash Suralaya } & \multicolumn{2}{c|}{ Fly Ash Bangka } \\
\hline \multirow{2}{*}{ hari } & \multicolumn{2}{|c|}{ Kuat Tekan Rata-rata } & \multicolumn{2}{c|}{$\begin{array}{c}\text { Kuat Tekan Rata- } \\
\text { rata }\end{array}$} & \multicolumn{2}{c|}{ Kuat Tekan Rata-rata } \\
\cline { 2 - 7 } & $\mathbf{K g} / \mathbf{C m}^{2}$ & $\mathbf{M P a}$ & $\mathbf{K g} / \mathbf{C m}^{2}$ & $\mathbf{M P a}$ & $\mathbf{K g} / \mathbf{C m}^{\mathbf{2}}$ & $\mathbf{M P a}$ \\
\hline 7 & 368,585 & 30,595 & 365,105 & 30,305 & 379,015 & 31,460 \\
\hline 14 & 392,925 & 32,615 & 424,220 & 35,210 & 434,650 & 36,075 \\
\hline 28 & 475,217 & 39,443 & 443,927 & 36,847 & 434,650 & 36,077 \\
\hline
\end{tabular}

Sumber : Hasil Pengolahan Data

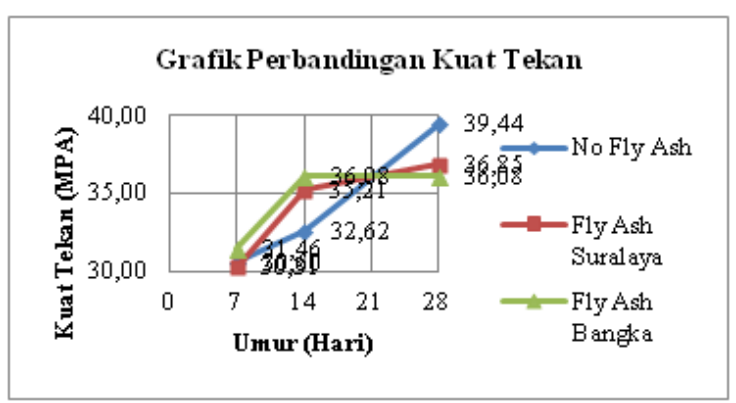

Gambar 6. Hasil Kuat Tekan Beton Semua Variasi

\section{Hasil Pengujian Nilai Slump}

Hasil nilai slump test yang menggunakan fly ash $11 \mathrm{~cm}$ sedangkan tanpa fly ash $13 \mathrm{~cm}$ dapat dilihat Tabel 19.

Tabel 19. Hasil Slump Test

\begin{tabular}{|c|c|}
\hline Sampel & $\begin{array}{c}\text { Nilai slump beton } \\
(\mathbf{C m})\end{array}$ \\
\hline Tanpa Fly Ash & 13 \\
\hline Suralaya & 11 \\
\hline Bangka & 11 \\
\hline
\end{tabular}

Sumber : Hasil Pengolahan Data

\section{Hasil Pengujian Kuat Tarik Belah Beton}

Hasil kuat tarik belah beton dengan penambahan SF 4\%, SP 2\%, dan Karet 5\% dengan fly ash $10 \%$ pada umur 28 hari berdasarkan SNI 032491-2002 $2^{13}$ dengan alat Compression test dapat dilihat pada table 4.8 berikut :

Tabel 20. Hasil Kuat Tarik Belah Beton Semua Variasi

\begin{tabular}{|c|l|c|c|c|c|c|}
\hline No & Variasi & $\begin{array}{c}\text { Umur } \\
(\text { hari })\end{array}$ & $\begin{array}{l}\text { Luas } \\
(\pi \mathrm{LD}) \\
\left(\mathbf{m m}^{2}\right)\end{array}$ & $\begin{array}{l}\text { Berat } \\
(\mathrm{kg})\end{array}$ & $\begin{array}{l}\text { Beban } \\
(\mathrm{kN})\end{array}$ & $\begin{array}{c}\text { Kuat tarik } \\
\text { Belah } \\
(\mathrm{MPa})\end{array}$ \\
\hline 1 & $\begin{array}{l}\text { NFA + SF 4\% } \\
+\quad \text { SP 2\% + } \\
\text { Karet 5\% }\end{array}$ & 28 & $\begin{array}{c}141.3 \\
71,7\end{array}$ & 12,31 & 190 & $\mathbf{2 , 6 8 9}$ \\
\hline 2 & $\begin{array}{l}\text { FAS 10\%+SF } \\
4 \%+\text { SP 2\%+ } \\
\text { Karet 5\% }\end{array}$ & 28 & $\begin{array}{c}141.3 \\
71,7\end{array}$ & 12,03 & 180 & $\mathbf{2 , 5 4 8}$ \\
\hline 3 & $\begin{array}{l}\text { FAB 10\%+ SF } \\
4 \%+\text { SP 2\%+ } \\
\text { Karet 5\% }\end{array}$ & 28 & $\begin{array}{c}141.3 \\
71,7\end{array}$ & 12,03 & 210 & $\mathbf{2 , 9 7 2}$ \\
\hline
\end{tabular}

Sumber : Hasil Pengolahan Data

\section{Setting Time Beton}

Dapat dilihat dari data seluruh sampel beton dengan penambahan SF 4\%, SP 2\%, dan Karet 5\%, yang memiliki waktu tercepat untuk mencapai kuat desak 500 Psi (Initial Setting Time) adalah beton tanpa fly ash. Dengan kemampuan pemadatan beton sendirinya tersebut memiliki tingkat daya waktu ikat awal, di mana proses pengikatan atau proses hidrasi sudah terjadi dan panas hidrasi sudah muncul, serta workability beton sudah hilang. Sampel yang menghasilkan Initial Setting Time terlama adalah beton fly ash Bangka jenis $C$ dibandingkan fly ash suralaya jenis $F$, hal ini dikarenakan komposisi fly ash dan silica fume yang sangat banyak membuat suhu semakin rendah sehingga ikatan awal yang terjadi menjadi lambat.

Tabel 21. Hasil Setting Time Beton Semua Variasi

\begin{tabular}{|c|c|c|c|c|c|c|c|c|c|c|}
\hline \multirow[b]{2}{*}{ No } & \multirow[b]{2}{*}{$\begin{array}{c}\text { Luas } \\
\text { Penampang } \\
\text { (sq/in) }\end{array}$} & \multicolumn{3}{|c|}{ Beton Tanpa Fly Ash } & \multicolumn{3}{|c|}{ Beton Fly Ash Suralaya } & \multicolumn{3}{|c|}{ Beton Fly Ash Bangka } \\
\hline & & $\begin{array}{l}\text { Umur } \\
\text { (mnt) }\end{array}$ & $\begin{array}{l}\text { Penetrasi } \\
\text { (lbf) }\end{array}$ & $\begin{array}{l}\text { Perlawanan } \\
\quad \text { (Psi) }\end{array}$ & $\begin{array}{l}\text { Umur } \\
\text { (mnt) }\end{array}$ & $\begin{array}{c}\text { Penetra } \\
\text { si } \\
\text { (lbf) }\end{array}$ & $\begin{array}{c}\text { Perlaw } \\
\text { anan } \\
\text { (Psi) }\end{array}$ & $\begin{array}{l}\text { Umur } \\
\text { (mnt) }\end{array}$ & $\begin{array}{c}\text { Penetra } \\
\text { si } \\
\text { (lbf) }\end{array}$ & $\begin{array}{c}\text { Perlaw } \\
\text { anan } \\
\text { (Psi) }\end{array}$ \\
\hline 1 & 1 & 60 & 0 & 0 & 60 & 0 & 0 & 120 & 3 & 3 \\
\hline 2 & 1 & 120 & 26 & 26 & 90 & 20 & 20 & 180 & 27 & 27 \\
\hline 3 & $1 / 2$ & 150 & 29 & 58 & 120 & 38 & 38 & 225 & 45 & 45 \\
\hline
\end{tabular}




\begin{tabular}{|c|c|c|c|c|c|c|c|c|c|c|}
\hline 4 & $1 / 2$ & 180 & 45 & 90 & 150 & 29 & 58 & 255 & 31 & 62 \\
\hline 5 & $1 / 4$ & 195 & 27 & 108 & 180 & 50 & 100 & 285 & 47 & 94 \\
\hline 6 & $1 / 4$ & 210 & 33 & 132 & 240 & 40 & 160 & 330 & 43 & 172 \\
\hline 7 & $1 / 4$ & 240 & 50 & 200 & 300 & 26 & 260 & 360 & 27 & 270 \\
\hline 8 & $1 / 10$ & 270 & 31 & 310 & 330 & 34 & 340 & 390 & 38 & 380 \\
\hline 9 & $1 / 20$ & $\mathbf{3 0 0}$ & 26 & $\mathbf{5 2 0}$ & $\mathbf{3 9 0}$ & 26 & $\mathbf{5 2 0}$ & $\mathbf{4 3 5}$ & 28 & $\mathbf{5 6 0}$ \\
\hline
\end{tabular}

Sumber : Hasil Pengolahan Data

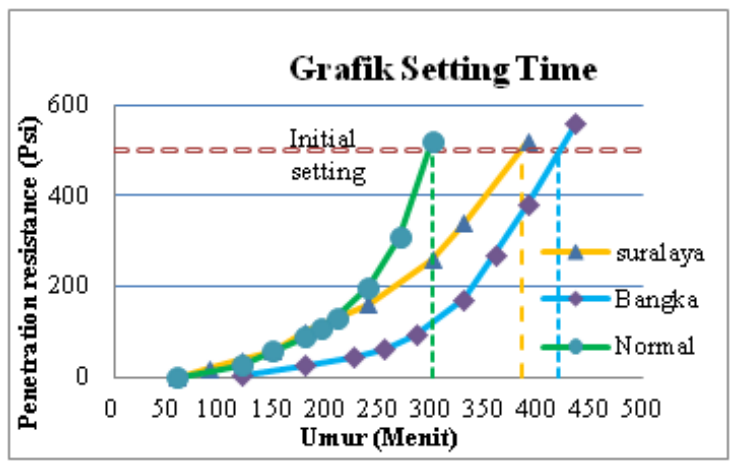

Gambar 7. Grafik Setting Time Beton Semua Variasi

\section{Kesimpulan}

1. Klasifikasi berdasarkan pengujian parameter abu terbang (fly ash) dari PLTu Bangka termasuk kategori Kelas C dimana $\mathrm{SiO} 2+$ $\mathrm{Al} 2 \mathrm{O} 3+\mathrm{Fe} 2 \mathrm{O} 3>50$ sedangkan fly ash dari PLTU Suralaya termasuk Kelas F karena > 70.

2. Slump Test beton menggunakan SF 4\%, SP 2\%, dan Karet 5\%, tanpa NFA mempunyai nilai $13 \mathrm{~cm}$, sedangkan untuk yang menggunakan FA $10 \%$ Suralaya maupun FA $10 \%$ Bangka slump testnya $11 \mathrm{~cm}$.

3. Setting time pada beton menggunaan SF $4 \%$, SP 2\%, dan Karet 5\%, tanpa NFA mengalami waktu tercepat initial seting time yaitu 300 menit dan terlama pada beton FA 10\% Bangka initial setting time pada waktu 435 menit sedangkan initial setting time untuk beton dengan FA10\% Suralaya yaitu 390 menit,

4. Penggunaan SF 4\%, SP 2\%, dan Karet 5\%, kuat tekan beton tertinggi tanpa FA yaitu sebesar 39,44 MPa dan kuat tekan terendah dengan FA $10 \%$ Bangka sebesar 36,08 $\mathrm{MPa}$ sedangkan kuat tekan dengan FA $10 \%$ Suralaya sebesar $36,85 \mathrm{MPa}$

5. Penggunaan SF 4\%, SP 2\%, dan Karet 5\%, kuat tarik belah beton untuk tanpa NFA sebesar 2,689 $\mathrm{MPa}$ dan dengan FA $10 \%$ Bangka sebesar 2,972 MPa sedangkan dengan FA $10 \%$ Suralaya sebesar 2,548 MPa

\section{DAFTAR PUSTAKA}

[1] Nadin, Naser. (2012). Perilaku lentur Beton Yang menggunakan /limbah Ban Bekas Sebagai Agregat.

[2] Pane Azis. (2012). Krisis Ekspor Ban Melambat Kementrian Perindustrian. Sumber Koran Sindo.

[3] Mardiono. (2011). Pengaruh Pemanfaatan Abu Terbang (Fly Ash) Dalam Beton Mutu Tinggi. Skripsi. Sarjana. Teknik Sipil. Universitas Gunadarma Jakarta.

[4] I Wayan Suarnita. (2011). /kuat Tekan Beton Dengan Aditif Fly Ash Ex. PLTU Mpanau Tavaeli. Jurnal Smart Universitas Tadulako, Palu.

[5] Badan Standarisasi Nasional. (1991). Spesifikasi Abu Terbang Sebagai Bahan Tambahan untuk Campuran Beton. SNI 032460-1991.

[6] Annual book of ASTM Standard. Designation C 403 / C 403 M-99. Standard Test Method for Time of Setting of Concrete Mixtures by Penetration Resistance.

[7] Annual book of ASTM Standard. Designation C 40 - 92. Standard Test Method for Organic Impurities in Fine Aggregates for Concrete.

[8] Badan Standarisasi Nasional. (2013). Persyaratan Beton Struktural Untuk Bangunan Gedung. SNI 03-2847-2013

[9] Badan Standarisasi Nasional. (2002). Persyaratan Beton Struktural Untuk Bangunan Gedung. SNI 03-2847-2002

[10] Badan Standarisasi Nasional. (2000). Tata Cara Pembuatan Rencana Campuran Beton Normal. SNI 03-2834-2000

[11] Badan Standarisasi Nasional. (2013). Cara Uji Slump Beton. SNI 1972-2013.

[12] Badan Standarisasi Nasional. (2002). Metode Pengujian Analisis Saringan Agregat Halus dan Kasar. SNI 03-6820-2002.

[13] Badan Standarisasi Nasional. (1990). Metode Pengujian Kadar Air Agregat. SNI03-19711990.

[14] Badan Standarisasi Nasional. (2011). Cara Uji Kuat Tekan Beton Dengan Benda Uji Silinder. SNI 1974-2011 